\title{
Leisure reading: a case study of adolescent readers at Letlhabile Community Library
}

\author{
Chrisaldah Tlou ${ }^{1}$ and Maritha Snyman ${ }^{2}$ \\ ctlou@nwpg.gov.za ORCID: 0000-0002-2010-139X \\ snyman.maritha@gmail.com ORCID: 0000-0001-8594-0998
}

Received: 24 January 2019

Accepted: 3 June 2020

\begin{abstract}
Literature on the topic of reading habits shows that reading for leisure benefits children and adolescents in numerous ways. It improves their vocabulary and literacy skills, it encourages self-development and provides young adults with entertainment, relaxation and a means to escape (McKool 2007: 111). The aim of this study was to investigate the reading habits of adolescents in Let/habile in terms of practise and perception. The study used a mixed methods research approach and collected data from a total of 290 respondents with the aid of questionnaires and a focus group. The researchers wanted to establish how adolescents in Let/habile perceive leisure reading, to what extent they participate in reading for leisure, and how leisure reading can be promoted in this community. The data collected from the mixed methods approach revealed contradictory findings that a questionnaire alone would not have revealed. The research approach was thus successful, but the findings were not enough to explore and meet fully all the aims of the research. It was, however, found that respondents were aware of the benefits of leisure reading and that they had good ideas about how leisure reading could be promoted in their community.
\end{abstract}

Keywords: Leisure reading, adolescents, reading culture, reading habits, rural, South Africa

\section{Introduction}

The lack of reading among South African learners is probably the biggest impediment to growth in South Africa. Given the lack of proper teaching of reading in schools over the last twenty-four years, a whole generation is deficient in reading skills and consequently find it difficult to study, develop their careers or find work. This appalling state of affairs was highlighted in, among others, the PIRLS 2006 International Report (Mullis et al. 2007). Forty countries participated in this reading literacy study for primary schools and South Africa's score was the lowest out of all countries. More than half of Englishspeaking and Afrikaans-speaking learners and over $80 \%$ of African language speakers did not reach the international benchmark for reading (Howie, Venter \& Van Staden 2008). This means that many South African primary school readers do not have the basic reading proficiency that would enable them to cope with their studies.

Research has focused on the primary school environment (Lategan 1999, Pretorius \& Ribbens 2005, Snyman 2006). A few studies have attempted to establish what the reading culture and habits of high school learners or adolescents are. Although findings must ideally be converted into actions to have an impact, research can be used to improve the dire state of reading in South Africa. This paper is based on research that sought to determine what the reading status is of adolescents in one rural South African community. Although this is a small case study about the leisure reading habits of learners who frequent one public library in their community - their only source of information - interesting findings came to light: some positive and some negative.

\section{Leisure reading and adolescents}

Leisure reading can be defined as reading for pleasure, as opposed to reading for an assignment (Mellon 1990 cited in Hughes-Hassell \& Rodge 2007: 22). It is "reading done at the reader's own free will ... [and] involves material that reflects the reader's own choice, at a time and place that suits him[/her]" (Clark \& Rumbold 2006: 6). Terms like 'self-selected reading', 'independent reading', 'voluntary reading' and 'reading for pleasure' are all used to refer to leisure reading (Clark \& Rumbold 2006, Krashen \& McQuillan 2007, Hughes-Hassell \& Rodge 2007, McDougal 2011). Leisure reading includes silent reading, reading aloud, online reading and listening to audiobooks, and encompasses fiction and non-fiction (Moyer 2011: 58). In this research, the concept of leisure reading is mainly based on the views of Krashen and McQuillan (2007),

1. Chrisaldah Mapula Tlou completed her master's degree at the University of South Africa and is a librarian at Letlhabile Community Library, South Africa

2. Maritha Snyman is Associate Professor in the Department of Information Science at the University of South Africa 
Hughes-Hassell and Rodge (2007) and McDougal (2011). Self-selected reading is influenced by feelings; readers can choose to stop reading when they like, without consequences (Krashen \&McQuillan 2007: 2). In voluntary independent reading, the times and places where reading occurs do not matter (McDougal 2011: 15). The reader is an active role player in reading for leisure (Ross 2009: 174), able to make predictions about the author's intentions of how the story will unfold. In a study conducted by Ibarra-Guyos (2013: 4), the author eloquently describes how, for many, leisure reading is about the magic and escape that a great story can make possible. This journey is called experience-taking (Garro 2014: 15).

Research indicates that reading for leisure benefits children and adolescents in numerous ways. It improves vocabulary and literacy skills, encourages self-development and provides young adults with entertainment, relaxation and a means to escape from reality (McKool 2007: 111). Leisure reading is often perceived as a habit that contributes to success in life. Success could include possessing academic skills that impact on personal development and everyday life (Holden 2004) and is at the heart of self-education and lifelong learning (Tella \& Akande 2007: 121). The more adolescents read for leisure, the more they become decision makers and problem solvers in their daily lives (Garro 2014: 4). Leisure reading improves self-identity and self-awareness in adolescents (Howard 2011: 48). It is fun and relaxing, at the same time allowing readers to learn new things; it is an antidote for boredom (Hughes-Hassell \& Rodge 2007: 22). Based on the notion that readers identify with characters in the books they like to read, Strommen and Mates (2004) and Howard (2011) claim that leisure reading helps adolescents better understand the people around them, giving them an insight into others' lives. A South African study by Phasha, McClure and Magano (2012: 322) attributed additional benefits to leisure reading, namely the facilitation of communication and academic success. Adolescents who do not enjoy leisure reading read less and eventually struggle to maintain an acceptable reading level (Brozo, Shiel \& Topping 2007: 307). Reading proficiency increases with the amount of time spent on voluntary reading (American Library Association 2006).

\subsection{Leisure reading and reading attitude}

It is the attitude of an adolescent towards reading material that determines whether an interest in reading for leisure will develop. Reading attitude is associated with "feelings towards [the reading matter]" (McClure 2011: 31). If adolescents do not feel positive about what they are reading, they will not enjoy the benefits that come with reading. Attitude is learned and not innate (McKenna et al. 2012: 284). A positive attitude towards leisure reading material can reinforce reading interest. Mathewson's (2004: 143) reading model suggests that the lack of an intention to read may lead to non-engagement with reading material. The intention to read is influenced by external and internal factors. External motivation rewards children if they read, while internal motivation is associated with an individual child's feelings about the available reading material. Therefore, the provision of books that are of interest to adolescents can have a lasting effect on their reading attitude (McKenna 1994: 31). Reading attitude is also influenced by people in society. McKenna's model of reading attitude acquisition (1994: 31) demonstrates how the formation of reading attitude comprises social and environmental aspects, beliefs, subject norms, the intention to read, attitude towards reading and the decision to read. Adolescents are influenced to read for leisure by friends, parents and teachers (Hughes-Hassell \& Rodge 2007, Tiemensma 2009: 122, Kutay 2014: 39). Librarians can play a considerable role in inculcating a culture of reading in their communities.

\subsection{Leisure reading and technology}

Reasons for not wanting to read are often attributed to the current generation's advanced relationship with technology (Beastall 2006: 97). The National Endowment for the Arts (2007) in the United Kingdom found a 14\% decline in daily readers among 13-year-old children. The source emphatically states that adolescents appear to be involved in other activities rather than reading, such as, chatting to friends via text message. Substantial evidence in the same vein is presented in a study conducted by Hughes-Hassell and Rodge (2007), which indicated that $37 \%$ of adolescents would rather browse the internet than read. The view that internet usage does not equate to reading is not, however, shared by all. Rather than decreasing the amount of leisure reading, technology can increase it because adolescents now have a medium of choice on which to read (Hughes-Hassell \& Rodge 2007: 22). Texting via mobile phones, surfing the internet and playing computer games are now being associated with reading achievement (Guthrie, Morrison \& Klauda 2012: 11). Moreover, using more than one type of media at the same time shows that adolescents can multi-task:

They can read and text at the same time, watch television and access the internet from their cell phones and they can read whilst listening to the music (Garro 2014: 19).

The challenge is to encourage adolescents to maintain a balance between reading study-related material and leisure reading material. 


\section{Context of study}

The economy of the North West province of South Africa is dominated by mining, followed by manufacturing, agriculture and construction (North West Development Corporation 2019). The number of employed persons increased in the North West province between quarter one and quarter two of 2019 by 52,000 but there was an increase in the unemployment rate of $6.9 \%$, while the percentage of people living in poverty was stated as marginally lower than the national average (North West Development Corporation 2019: 17). The location of the study on which this research is based is the Letlhabile Community Library, situated on the outskirts of Brits in the Madibeng Municipality in the Bojanala district of North West Province (South Africa). According to the 2011 population census, the population of Madibeng was estimated to be 477,381 while the population in Letlhabile was 41,497 (Statistics South Africa 2011). In the Bojanala district, $51.9 \%$ of the population live below the upper-bound poverty line. The official unemployment level is $26.5 \%$

Madibeng Municipality has established nine libraries apart from the main library in Brits of which Letlhabile Community Library is one. These ten libraries rely on funding from the municipal budget and support from the province's Department of Culture, Arts and Traditional Affairs. Letlhabile Community Library provides services to all residents of Letlhabile and neighbouring villages. This community library houses 14,000 items consisting of books, periodicals, maps, pamphlets, government publications, newspapers, magazines and directories. These information sources are selected and purchased according to the needs of the community. Although, in general, the library meets the community's requirements in terms of leisure reading, books for leisure reading are not being read by adolescents. For example, statistics indicated that the borrowing of fiction books in the adolescents' section of the library fell dramatically in 2014 . Additionally, there is a disparity between the borrowing pattern of books in the nine libraries, which are used mainly by the black community, and the Brits main library in town. As reported by librarians (personal communication 2014), in April 2014, only 112 fiction books were issued to children and adolescents in Letlhabile, while 3,000 fiction books were borrowed by children and adolescents from the Brits main library.

One of the researchers in this study is a librarian at the Letlhabile Community Library and works actively with the children that visit her library. She encourages reading for primary school learners through library programmes. She observed that, once the children progress to high school, they no longer actively participate in library programmes and, consequently, stop reading fiction. While adolescents use the library more than their adult counterparts, they do so mainly to complete school projects. They seem to believe that libraries mainly exist for assisting with school projects. The aim of this paper is to report on the research that originated from these observations by the Letlhabile Community Librarian. The librarian wanted to investigate the reading habits of adolescents in Letlhabile and determine how they practise and perceive the notion of leisure reading. Research was conducted, firstly, to try and determine the reading behaviour of the adolescents who visit Letlhabile library and, secondly, to discover how their behaviour can be positively changed.

\section{Methodology}

Both quantitative and qualitative data collection methods were used to investigate the leisure reading habits of adolescents that frequent the Letlhabile library. This mixed methods approach is useful to discover patterns and to uncover "the best of a set of explanations for understanding" behaviour (Creswell 2003, Onwuegbuzie \& Leech 2006: 17, Johnson, Onwuegbuzie \& Turner 2007). The approach was used in a case study research design to enable an intensive investigation and detailed description of the reading habits of Letlhabile's adolescents (Gilbert 2008: 36, Christensen, Johnson \& Turner 2011: 374).

The research population for this study was adolescents between the ages of 14 and 19 years who use the Letlhabile Community Library frequently (visit the library roughly six days a week). This group has a good understanding of the available information sources in the library which they mainly use for school assignments. A questionnaire was designed to collect relevant qualitative and quantitative data from respondents about their leisure reading habits. Twenty closed-ended questions were included in the questionnaire which were sourced and adapted from prior studies, including those of HughesHassell and Lutz (2006), Hughes-Hassell and Rodge (2007) and Smith (2009), that also focused on the leisure reading habits of adolescents. A pilot study was carried out. Problems found were corrected to ensure the validity of the final instrument. A sample of the research population, which consisted of adolescents that frequent the library, was selected by sequential sampling (Onwuegbuzie \& Leech 2006). Every ninth person that had appeared over the previous six months on the library's register at the security desk as well as on the register of the daily Public Internet Access (PIA) was selected. On these registers, age and gender must be filled in for statistical purposes. This data helped to identify the adolescent population of active library users. The total number of the adolescents in the register was 2,618. The total number included in the sample was 290. Questionnaires were distributed and completed in the library to ensure a fast return rate. The completed questionnaires were collected and kept in a safe place.

Qualitative data was collected via a focus group discussion. For the focus group, a purposive sample was drawn from those who responded to the questionnaire. Adolescents were selected according to the following criteria: those who 
attended library programmes, were known to the researcher, and who had built a relationship with the library staff from their early primary school years. Five male and five female adolescents were selected to gain in-depth knowledge of their prehigh school leisure reading habits. The focus group discussion was considered an important tool in trying to understand how the adolescents think and feel about issues related to them (Krueger \& Casey 2001, Rabiee 2004: 656). A schedule containing twenty open-ended questions was developed. Questions dealt with issues like reading attitude, leisure reading behaviour and reading motivation. The focus group discussion took place in a private room of the library. The participants sat in a semi-circular with the researcher in front and the scribe, who recorded the discussion and made notes, at the back of the group. The discussion lasted for an hour. The scribe's notes and the transcribed recording of the focus group discussion were then analysed by the researchers.

\section{Data analysis}

Data analysis followed the seven stages for analysing data collected in mixed methods research as suggested by Onwuegbuzie and Leech (2006: 492): data reduction, data display, data transformation (when the quantitative/qualitative data are converted into words/numerical codes), data correlation (linking qualitative data with quantitative data, or vice versa), data consolidation (the combination of qualitative and quantitative data to create new variables), data comparisons between qualitative and quantitative data, and data integration (integration of qualitative and quantitative data into a single data set). The quantitative data were entered into an Excel spreadsheet to order it and make analysing it manageable and so that it could be displayed in tables. The qualitative data that were collected from open-ended questions were read and re-read and patterns and themes were selected to organise the data. Responses in the focus group were numbered to ensure anonymity. Both sets of data were then combined to seek convergence or similarities, before both datasets were consolidated into a single set of findings. The themes that emerged from the consolidated data were categorised as: reading influences, time spent reading, how leisure time is spent, reading sources, reasons for reading, and types of reading material preferred. From these themes, the following main categories were identified: attitude towards reading, reasons for reading, reading choices and sources, and reading motivation. These categories are discussed below.

\subsection{Demographics of respondents}

The first two questions of the questionnaire sought to obtain demographic information about the respondents (Table 1). Fifty-one percent of participants were male and $49 \%$ female. Most of the respondents who took part in this study were 16 or 17 years old. Overall, there were more male respondents, particularly in the focus group discussion where two female respondents who were invited to the discussion did not turn up.

Table 1 Demographic information of respondents

\begin{tabular}{lcccc}
\hline Age group & Male & $\%$ & Female & $\%$ \\
\hline $14-15$ & 32 & $21.4 \%$ & 51 & $36.1 \%$ \\
$16-17$ & 60 & $40.2 \%$ & 55 & $39.1 \%$ \\
$18-19$ & 57 & $38.4 \%$ & 35 & $24.8 \%$ \\
TOTAL & $\mathbf{1 4 9}$ & $\mathbf{1 0 0} \%$ & $\mathbf{1 4 1}$ & $\mathbf{1 0 0 \%}$ \\
\hline
\end{tabular}

\subsection{Attitude towards reading}

In this category, a few themes were identified as influencing the respondents' attitudes towards reading.

\subsubsection{Hours per day spent on reading}

Question 3 of the questionnaire asked: "How many hours do you spend reading per week?" (see Table 2). At first, it seemed as if the respondents do allocate time for leisure reading. It became clear later, however, that these responses were contradictory and possibly not true.

Table 2 Hours per day spent on reading by adolescents in Letlhabile

\begin{tabular}{lcc}
\hline Hours spent reading per day & N & $\%$ \\
\hline Two or more hours & 121 & $41.7 \%$ \\
One hour & 94 & $32.4 \%$ \\
Less than an hour & 31 & $10.7 \%$ \\
Other (More than three hours) & 44 & $15.2 \%$ \\
TOTAL & $\mathbf{2 9 0}$ & $\mathbf{1 0 0} \%$ \\
\hline
\end{tabular}


The issue of how much time was spent on reading was also discussed in the focus group. Responses varied and included:

- I don't read much, like, for leisure, I read for less than 30 minutes (F8)

- I read for one hour (F10, F4, F7, F6 \& F2)

- I read for two hours (F3)

- I read for three hours (F5).

Other South African studies do not corroborate the findings of reading for an hour or more. Phasha, McClure \& Magano (2012: 322) and (McClure 2011: 55) found that adolescents in South Africa spent between 0-20 minutes per day reading for leisure. Responses in this study about how much time was spent per day reading were contradicted by responses to the question about the sources of reading material (4.4) as well as the clear confusion about how leisure reading differs from reading for school. Therefore, no conclusive finding could be obtained, except that all respondents knew that reading is a beneficial activity.

\subsubsection{Leisure time activities}

The responses to the questions about how leisure time is spent suggested that, among the respondents, internet browsing and spending time on social media were more popular than reading, watching television and even spending time with friends (Table 3). Most of the males (45.6\%) and $24.1 \%$ of females spent most of their leisure time browsing the internet. Female respondents showed a greater preference for texting friends while male respondents preferred to "hang out" with friends. A small group indicated that they spend their free time sleeping or listening to music. In this study, reading seemed to face competition from technology. In the focus group discussion, the perception that more leisure time is spent on "cyberspace and on the internet" (F3, F5), and on social media (F7), was confirmed. Both the quantitative and qualitative findings indicated that browsing the internet is the most favoured activity of most respondents. This is not surprising, as other studies have shown that the current generation has an advanced relationship with technology almost from birth (Beastall 2006: 97).

In light of these findings, the best option for encouraging reading is perhaps to make reading accessible online. Young readers may find it easier to read online than read a printed book. One respondent in the focus group discussion said: "Having free Wi-Fi in the library would allow [easier] reading through the use of cell phones than to read a book page by page" (F8). This suggestion caused friction among the other respondents as some felt that only those who have access to smart phones would benefit from accessing Wi-Fi in the library. This incident exposed the inequality in income and economic status of the group as a reflection of the community. The research findings suggest that texting and surfing the internet, computer games and similar activities are a hindrance to reading for leisure.

Table 3 How do adolescents in Letlhabile spend their free time?

\begin{tabular}{lccccc}
\hline Variables & $\mathbf{M} / \mathbf{F}$ & Male & $\%$ & Female & $\%$ \\
\hline Reading (e.g. books, magazines, newspapers) & $53(18.2 \%)$ & 16 & $10.7 \%$ & 37 & $26.2 \%$ \\
Watching television & $47(15.8 \%)$ & 21 & $14.1 \%$ & 26 & $17.7 \%$ \\
Browsing the internet & $102(35.2 \%)$ & 68 & $45.6 \%$ & 34 & $24.1 \%$ \\
Using text messages to communicate with friends & $41(14.1 \%)$ & 11 & $7.4 \%$ & 30 & $21.2 \%$ \\
Hanging out with friends & $38(13.2 \%)$ & 28 & $18.8 \%$ & 10 & $7.1 \%$ \\
Sleeping & $5(2.1 \%)$ & 2 & $1.3 \%$ & 4 & $2.8 \%$ \\
Listening to music & $4(1.4 \%)$ & 3 & $2.1 \%$ & 1 & $0.7 \%$ \\
TOTAL & $\mathbf{2 9 0}$ & $\mathbf{1 4 9}$ & $\mathbf{1 0 0} \%$ & $\mathbf{1 4 2}$ & $\mathbf{1 0 0 \%}$ \\
\hline
\end{tabular}

\subsubsection{Types of readers}

Most questionnaire respondents $(134 ; 46.4 \%)$ indicated that they 'liked' to read, while $129(44.4 \%)$ claimed that they were keener readers and actively enjoyed reading (Table 4). Only fifteen $(5.1 \%)$ of the respondents did not read and $4.1 \%$ said they did not like to read. The majority of respondents (53.4\%) also indicated that they read frequently (Table 5). Here, the possibility that the responses were given to impress the researcher cannot be ruled out. When compared to the findings from the questionnaire, the qualitative data provided more candid responses: "I don't read, and I have no interest in reading for leisure" (F5) and "I read for leisure when I have not too much school work" (F3). These responses indicated perhaps that the respondents focused their reading on schoolwork, an important reason for the lack of a leisure reading culture in South Africa. The negative attitude of respondents who declared reading boring will hinder their reading achievement and their own development (McClure 2011: 85). They will forfeit the self-identity and self-awareness that come with reading (Howard 2011: 48). Reading just for school is an attitude that impedes reading for leisure. 
Table 4 Which statement describes you best?

\begin{tabular}{lcc}
\hline Description & $\mathbf{N}$ & $\%$ \\
\hline I am a keen reader and I enjoy reading & 129 & $44.4 \%$ \\
I like reading, but I don't seem to read much in my free time & 134 & $46.4 \%$ \\
I have too many things to do to find time for reading & 15 & $5.1 \%$ \\
I don't like reading & 12 & $4.1 \%$ \\
TOTAL & $\mathbf{2 9 0}$ & $\mathbf{1 0 0 \%}$ \\
\hline
\end{tabular}

Table 5 How often would you read if you had time?

\begin{tabular}{lcc}
\hline Frequency of reading & $\mathbf{N}$ & $\%$ \\
\hline Frequently & 155 & $53.4 \%$ \\
Sometimes & 83 & $28.6 \%$ \\
Rarely & 28 & $9.6 \%$ \\
Never & 24 & $8.4 \%$ \\
TOTAL & $\mathbf{2 9 0}$ & $\mathbf{1 0 0} \%$ \\
\hline
\end{tabular}

\subsubsection{Being read to when young}

Almost $50 \%$ of the respondents' parents either rarely or never read to them when they were young (Table 6). Findings about the lack of extensive literacy practices in families have been documented in other studies (for example, Pretorius \& Ribbens 2005, Paratore \& Dougherty 2011). Other South African studies indicated that a lack of books in African households inhibits children from becoming leisure readers (Snyman 2006, Tiemensma 2009: 51).

Table 6 How often did the parents of adolescents in Letlhabile read to them?

\begin{tabular}{lcc}
\hline How often did your parents read to you? & $\mathbf{N}$ & $\%$ \\
\hline Frequently & 47 & $16.3 \%$ \\
Sometimes & 102 & $35.1 \%$ \\
Rarely & 50 & $17.2 \%$ \\
Never & 91 & $31.4 \%$ \\
TOTAL & $\mathbf{2 9 0}$ & $\mathbf{1 0 0} \%$ \\
\hline
\end{tabular}

\subsubsection{Books read per week}

Nearly half of the respondents (47.9\%) claimed that they read more than two books per week, $25.2 \%$ indicated that they read two books per week, while $26.9 \%$ claimed to read one book per week (Table 7 ). This contradicts the findings in Table 3 where only $18.2 \%$ of the respondents indicated that they read for leisure in their free time. In the focus group discussion, the responses varied from "I read one or two books" (F3); "At least one book" (F10, F1, F2, F7, F8 \& F5); "Two books" (F4) to "I read two books but in most cases I don't finish them" (F6).

Table 7 Number of books read by adolescents in Letlhabile

\begin{tabular}{lcc}
\hline Number of books read & N & $\%$ \\
\hline One book & 78 & $26.9 \%$ \\
Two books & 73 & $25.2 \%$ \\
More than two books & 139 & $47.9 \%$ \\
None & 0 & $0 \%$ \\
TOTAL & $\mathbf{2 9 0}$ & $\mathbf{1 0 0 \%}$ \\
\hline
\end{tabular}

\subsubsection{Preferred reading time}

The quantitative findings indicated that half of the respondents $(147 ; 50.6 \%)$ (Table 8 ) preferred to read at night-time, probably because nights are considered private time. In the focus group discussion, the respondents gave two answers: "I read at night" (F6, F7, F5. F3 \& F2) and "I read after school" (F1, F10, F4 \& F8). It seems that most of the respondents find night-time convenient for leisure reading. 
Table 8 When do adolescents in Letlhabile read?

\begin{tabular}{lcc}
\hline When is reading done? & $\mathbf{N}$ & $\%$ \\
\hline At night at home & 147 & $50.6 \%$ \\
After school in the library & 59 & $20.3 \%$ \\
On weekends & 18 & $6.2 \%$ \\
During school holidays & 21 & $7.2 \%$ \\
When I have spare time & 45 & $15.5 \%$ \\
TOTAL & $\mathbf{2 9 0}$ & $\mathbf{1 0 0} \%$ \\
\hline
\end{tabular}

\subsection{Why read for leisure?}

The majority of the respondents $(31.8 \%)$ read because their parents encourage them to read, probably because parents are aware that reading is a necessary skill. Table 9 shows that $22.7 \%$ of adolescents read for fun, while $8.4 \%$ of respondents read because they were bored and $18.9 \%$ read because teachers recommended books to them. Only $8.2 \%$ were encouraged by librarians. Some respondents added additional variables such as, to get more information (45.7\%), to learn new things $(8.5 \%)$, to be educated $(34.3 \%)$, to develop the brain $(2.9 \%)$, to be able to travel $(2.9 \%)$, to keep busy $(2.9 \%)$, and to improve themselves (2.9\%) (Table 10).

Table 9 Reasons for reading

\begin{tabular}{lcc}
\hline Variables & N & $\%$ \\
\hline Because my parents encourage me & 81 & $31.8 \%$ \\
For fun & 58 & $22.7 \%$ \\
Because my teacher recommends books to me & 48 & $18.9 \%$ \\
Because I am bored and have nothing to do & 47 & $8.4 \%$ \\
Because my librarian encourages me & 21 & $8.2 \%$ \\
TOTAL & $\mathbf{2 5 5}$ & $\mathbf{1 0 0 \%}$ \\
\hline
\end{tabular}

In the focus group discussion, similar reasons for reading were expressed by the respondents:

- $\quad$ To gain knowledge (F10)

- $\quad$ Reading encourages me to know more things around the world and exercise the brain cells (F8)

- It helps me to understand what is happening around the world as a young politician (F6)

- $\quad$ To gain knowledge and know what is happening around the world (F7).

The respondents were certainly aware of the positive contribution of leisure reading in their lives.

Table 10 More reasons why respondents read for leisure

\begin{tabular}{lcc}
\hline Other reasons & $\mathbf{N}$ & $\%$ \\
\hline To get more information & 16 & $45.7 \%$ \\
To be educated & 12 & $34.3 \%$ \\
To learn new things & 3 & $8.5 \%$ \\
To improve myself & 1 & $2.9 \%$ \\
Reading keeps me busy & 1 & $2.9 \%$ \\
So that I can travel to places & 1 & $2.9 \%$ \\
Reading supports the brain & 1 & $2.9 \%$ \\
TOTAL & $\mathbf{3 5}$ & $\mathbf{1 0 0 \%}$ \\
\hline
\end{tabular}

\subsection{Reading choices and sources}

An unexpected finding was that $40.9 \%$ of the male respondents read fiction, while only $22.6 \%$ of the female respondents do so (Table 11). This indication, that males read more fiction than females, supports the findings of Smith (2009: 102), but is not corroborated by the research of Hughes-Hassell and Rodge (2007: 25), the South African Book Development Council (2007: 12) and McClure (2011: 77). Fiction in this study was the most popular reading material for both genders $(32.1 \%)$, 
followed by magazines (30\%), non-fiction ( $20 \%)$ and newspapers $(18.9 \%)$. The fact that $46.1 \%$ of the female respondents preferred magazines concurs with the trend described by Strommen and Mates (2004), Hughes-Hassell and Rodge (2007: 25), Howard (2011) and McClure (2011: 74). The preferred reading material of males was newspapers, which is consistent with the findings of a study conducted by Kutay (2014: 23). In the focus group discussion, respondents indicated their preference for reading material as follows:

- $\quad$ Novels (F10 \& F3)

- Science fiction (F6)

- $\quad$ Story books (F2 \& F1)

- Newspapers and magazines (F8)

- Political magazines (F7).

Table 11 Reading choices of adolescents in Letlhabile

\begin{tabular}{lccccc}
\hline Reading material & Male & $\%$ & Female & $\%$ & M/F \\
\hline Newspapers & 31 & $20.9 \%$ & 24 & $17.1 \%$ & $55(18.9 \%)$ \\
Fiction books & 61 & $40.9 \%$ & 32 & $22.6 \%$ & $90(32 \%)$ \\
Non-fiction books & 35 & $23.5 \%$ & 20 & $14.2 \%$ & $58(20 \%)$ \\
Magazines & 22 & $14.7 \%$ & 65 & $46.1 \%$ & $87(30 \%)$ \\
TOTAL & $\mathbf{1 4 9}$ & $\mathbf{1 0 0 \%}$ & $\mathbf{1 4 1}$ & $\mathbf{1 0 0 \%}$ & $\mathbf{2 9 0}(\mathbf{1 0 0} \%)$ \\
\hline
\end{tabular}

One of the respondents in the focus group discussion answered the question "What do you like to read?" as follows: "I like to read about animals" (F1). When asked "Why?" the respondent expressed himself in his mother tongue: "gore keitseketsedifengtse di lomang". This means: "So that I know which of the animals are dangerous". Other responses like, "I like to read about politics related material" (F7), "I like to read about inspirational people" (F3) and "I like to read about young people to know the challenges they are facing" (F10) enforce the inference that some respondents understood that reading develops knowledge about the world and politics. Unfortunately, it does not seem as if this knowledge has translated into positive reading practices.

\subsubsection{Finding leisure reading material}

The responses to the question "From where do you get your reading material?" highlighted the library as the main source (Table 12). In the focus group discussion, the same sources as those listed in the questionnaire were mentioned. It seems as if the library remains the most important source of reading material. In Letlhabile, the library supplies a unique service as it is the only place in the area that provides a selection of reading material. This finding concurs with those of Anderson et al. (2002) cited by Tiemensma (2009: 91).

Table 12 Sources of reading materials

\begin{tabular}{lcc}
\hline Variables & $\mathbf{N}$ & $\%$ \\
\hline The public library & 116 & $40 \%$ \\
School & 57 & $19.6 \%$ \\
A bookshop & 45 & $15.5 \%$ \\
Parents & 36 & $12.4 \%$ \\
Friends & 30 & $10.3 \%$ \\
Internet & 6 & $2.2 \%$ \\
TOTAL & $\mathbf{2 9 0}$ & $\mathbf{1 0 0} \%$ \\
\hline
\end{tabular}

\subsubsection{Why use the library?}

A follow-up question probed the responses above, and a large majority of respondents $(67.9 \%)$ used the library for study purposes; $19.6 \%$ used it to complete school projects, while only $1.7 \%$ used the library to borrow books. Slightly more than $3 \%$ of the respondents indicated that their library visits were related to knowledge seeking, while $7.2 \%$ of the respondents used the library for internet access (Table 13). These responses suggest that the purpose of using the library is largely unrelated to leisure reading requirements. In the focus group discussion, this impression continued. The following responses were provided: 
- To discuss schoolwork with students from other schools (F8)

- $\quad$ To access the internet (F3)

- For information and to study (F7, F4, F2, F5, F1, F10 \& F6).

Table 13 Reasons for library visits

\begin{tabular}{lc|c}
\hline Reasons for library visits & N & $\%$ \\
\hline To study & 197 & $67.9 \%$ \\
To complete school projects & 57 & $19.6 \%$ \\
To borrow books & 5 & $1.7 \%$ \\
\hline Other reasons & $\mathbf{N}$ & $\%$ \\
\hline To acquire knowledge & 10 & $3.6 \%$ \\
To access the internet & 21 & $7.2 \%$ \\
TOTAL & $\mathbf{2 9 0}$ & $\mathbf{1 0 0} \%$ \\
\hline
\end{tabular}

Respondents did not engage in leisure reading or borrowing books during library visits, even though $40 \%$ claimed that they find leisure reading material in the library. The library is almost solely used for study purposes as Tiemensma's research (2009: 85) also found. This is possibly because the library is only open during the day and most respondents indicated night-time as their preferred time for leisure reading.

\subsubsection{Visits to the library}

Regularity of visits to the library varied from frequently visiting the library (24.8\% of respondents) to sometimes visiting the library as indicated by $61.1 \%$ of respondents, to rarely visited the library $(11.7 \%)$. Only $2.4 \%$ of respondents never visited the library (Table 14).

Table 14 Frequency of library visits

\begin{tabular}{lcc}
\hline Library visits & N & $\%$ \\
\hline Frequently & 72 & $24.8 \%$ \\
Sometimes & 177 & $61.1 \%$ \\
Rarely & 34 & $11.7 \%$ \\
Never & 7 & $2.4 \%$ \\
TOTAL & $\mathbf{2 9 0}$ & $\mathbf{1 0 0} \%$ \\
\hline
\end{tabular}

In the focus group, the responses in relation to the frequency of library visits were:

- I visit the library three times a day (F4)

- Two times a day (F2)

- I visit the library every day (F10)

- Not always (F3, F6, F7, F8, F9 \& F5).

Clearly the respondents valued the library and its services.

\subsection{Reading motivation}

Responses to a variety of questions were used to gather information about reading motivation.

\subsubsection{Who encourages reading?}

Over forty-nine percent of the respondents indicated that their parents encouraged them to read; $24.1 \%$ were encouraged by teachers; $12.1 \%$ by friends; $11.7 \%$ by a sibling and only $2.4 \%$ by their librarian (Table 15 ). These results highlight the important role played by significant people in motivating adolescents to become readers. These findings are supported by other studies that found that a positive attitude towards reading is influenced by many people in society (Strommen \& Mates 2004: 198, Hughes-Hassell \& Rodge 2007: 23, Early 2011: 7, Howard 2011). The fact that the librarian is not really considered a significant person in promoting reading indicates the gap that exists in Lethabile. In the focus group discussion, the responses were mostly similar: 
- I am encouraged to read by the most successful people around me (F7)

- $\quad$ Parents (F10, F1, F2, F6 \& F4)

- $\quad$ Friends (F5 \& F8)

- $\quad$ Teachers (F10).

Here, as well, the librarian's role was not acknowledged.

Table 15 Reading encouragement

\begin{tabular}{lcc}
\hline Variables & N & $\%$ \\
\hline Parents & 144 & $49.6 \%$ \\
My teacher & 70 & $24.1 \%$ \\
Friends & 35 & $12.1 \%$ \\
Brother or sister & 34 & $11.7 \%$ \\
Librarian & 7 & $2.4 \%$ \\
TOTAL & $\mathbf{2 9 0}$ & $\mathbf{1 0 0} \%$ \\
\hline
\end{tabular}

\subsubsection{Reading at home}

Table 6 showed that only $16.3 \%$ of the respondents said that their parents read to them frequently. This is not surprising given that respondents were 14 years and above, so they are independent readers. The parents of the rest of the respondents read to them sometimes or rarely. The question "How many books does your family own?" was asked because the crucial role of parents in reading promotion is widely acknowledged. More than half $(51.7 \%)$ replied that their family owned ten or fewer books. Only $10 \%$ of the families owned twenty to fifty books (Table 16). The lack of books in respondents' homes will have a negative impact on reading proficiency. The accessibility of books to read is one of the most important factors in creating reading pleasure (Pretorius \& Ribbens 2005: 144, Snyman 2006). The question was phrased differently in the focus group discussion: "What types of books do you have at home?" The responses included:

- $\quad$ Story books (F1)

- History books (F2)

- Newspapers (F5)

- Different kinds of books including magazines (F9)

- $\quad$ Politics-related books and magazines (F7)

- Influential books (F8)

- Magazines (F10).

Reading material at home does clearly not include much fiction although what was meant by "story books" was not defined. The type of books available in homes was referred to as "socially engaged", "political related" and "influential". Based on the data presented in Table 16, it seemed that reading together as a family was not an activity that was often practised. These families have not developed a habit of reading. Library visits with parents are a rarity. This could mean that parents themselves are not library users. All respondents in the focus group discussions confirmed that their parents do not form part of their relationship with the library. The absence of parents in this regard can be seen as a stumbling block to foster an interest in reading (Strommen \& Mates 2004: 198). Only $12.7 \%$ of parents buy books for their children. It is not clear if the books referred to are for leisure reading only. The absence of parents in adolescents' reading habits are corroborated by other South African studies (Tiemensma 2009: 150, McClure 2011: 86, Phasha, McClure and Magano 2012: 324). The focus group discussion confirmed the trend: "My parents don't buy books for me. I get books from school and from the library" (F2, F1, F7 \& F10). In addition, friends seem to have taken over the role of parents in influencing a positive reading habit (as per Kutay 2014: 246): "I get books from friends" (F6, F4, F1, F8 \& F5). The fact that parents never bought leisure reading books suggests that there were other items that were considered a priority for their children or they did not have the money to do so or that they were not readers themselves. However, $51.7 \%$ of the respondents indicated that they had some (though fewer than ten) books at home which indicates that the reading development of respondents was not entirely unsupported. 
Table 16 Reading at home

\begin{tabular}{lc|c}
\hline Number of books owned by families & N & $\%$ \\
\hline 10 or fewer & 150 & $51.7 \%$ \\
$10-25$ & 72 & $25.2 \%$ \\
$20-50$ & 30 & $10 \%$ \\
More than 50 & 38 & $13.1 \%$ \\
TOTAL & $\mathbf{2 9 0}$ & $\mathbf{1 0 0 \%}$ \\
\hline How often does your family read together? & $\mathbf{N}$ & $\%$ \\
\hline Frequently & 35 & $12.1 \%$ \\
Sometimes & 141 & $48.6 \%$ \\
Rarely & 49 & $16.9 \%$ \\
Never & 65 & $22.4 \%$ \\
TOTAL & $\mathbf{2 9 0}$ & $\mathbf{1 0 0} \%$ \\
\hline Visits to the library with parents & $\mathbf{N}$ & $\%$ \\
\hline Frequently & 7 & $2.4 \%$ \\
Sometimes & 43 & $14.9 \%$ \\
Rarely & 24 & $8.2 \%$ \\
Never & 216 & $74.5 \%$ \\
TOTAL & $\mathbf{2 9 0}$ & $\mathbf{1 0 0 \%}$ \\
\hline How often do parents buy you books? & $\mathbf{N}$ & $\%$ \\
\hline Frequently & 37 & $12.7 \%$ \\
Sometimes & 136 & $46.9 \%$ \\
Rarely & 51 & $17.6 \%$ \\
Nover & 66 & $22.7 \%$ \\
\hline & $\mathbf{2 9 0}$ & $\mathbf{1 0 0 \%}$ \\
\hline
\end{tabular}

\subsection{Reading and gender}

It is widely believed that the reading attitudes of females towards leisure reading are more positive than those of males (Hughes-Hassell \& Rodge 2007: 24, Phasha, McClure and Magano 2012: 324). Some responses in this study suggest otherwise. This finding may be related to the socio-economic context of the study community (Pilgreen 2000: 1, Torgesen 2002: 8, Alexander et al. 1997 in Wasik, Bond \& Hindman 2006: 63) or it can be attributed to untruthful answers caused by an inability to understand the questionnaire or a desire not to disappoint the researcher.

\section{Reading promotion}

The question in the questionnaire, "Which activities would you like to see happening in the library that would make you read more?", elicited useful and creative responses from thirty-six respondents. The introduction of the following ideas was suggested: drama; fun games; more interesting books; reading competitions; leisure reading encouragement; reading corners; storytelling and poetry events; book clubs and writing competitions. These suggestions should be used by the librarian to introduce leisure reading material to adolescents. Since these are the respondents' own ideas, their implementation should encourage them to borrow books for home use. It seems that the adolescents would like to share books with peers and talk about them; they view leisure reading as a group, as well as an individual, activity. A book club seems a good place to start. In this manner, the library can become a popular place of leisure reading.

\section{Concluding comments}

This research attempted to provide a comprehensive view of how the adolescents in Letlhabile understand and practise leisure reading and how leisure reading can be promoted in this community. The findings of this study indicate that the respondents confused leisure reading with school-related reading, clearly reflecting a misunderstanding of the concept of leisure reading. The many contradictions in the responses of participants compromised the findings. These differences were found mainly when comparing the data from questionnaires and the focus group. This was possibly caused by the respondents' lack of understanding of the terms used and a need to impress the researcher. 
The contradictions found in the qualitative and quantitative data suggest that the mixed methods approach has advantages for explorative studies with first-time respondents. Although no conclusive findings were reached, practical solutions were highlighted through the combination of the quantitative and qualitative approaches used. The results of this study also point to the dearth of a reading culture, especially in South African rural areas. Children in disadvantaged communities are not exposed to literacy practices and suitable reading material in their home environments (Pretorius \& Ribbens 2005: 146, Mahwasane 2008: 116). This problem can be addressed through library outreach programmes to promote reading in those communities. This study draws attention to the different perceptions and attitudes of adolescents regarding leisure reading. The study also highlights the respondents' reading habits, how they perceive leisure reading and reasons why they read or do not read for leisure. The findings of this study may inform libraries about which route to take in the planning of programmes that can promote the leisure reading habits of adolescents. An important inference from this research is that the respondents in this study are aware that reading is beneficial to them and that it can broaden their knowledge base.

\section{References}

American Library Association. 2006. AASL position statement on the value of independent reading in the school library media program. [Online]. http://www.ala.org/aas//advocacy/resources/statements/ind-reading (23 May 2015).

Beastall, L. 2006. Enchanting a disenchanted child: revolutionising the means of education using information and communication technology and e-learning. British Journal of Sociology of Education, 27(1): 97-110.

Brozo, W.G., Shiel, G. and Topping, K. 2007. Engagement in reading: lessons learned from three PISA countries. Journal of Adolescent \& Adult Literacy, 51(4): 304-315.

Christensen, L.B., Johnson, B. and Turner, L.A. 2011. Research methods, design, and analysis. $12^{\text {th }}$ edition. Boston: Pearson.

Clark, C. and Rumbold, K. 2006. Reading for pleasure: a research overview. London: National Literacy Trust.

Creswell, J.W. 2003. Research design: qualitative, quantitative and mixed method approaches. $2^{\text {nd }}$ edition. Thousand Oaks, CA: Sage.

Early, J. 2011. Leisure reading habits: students' attitudes toward their in-school reading compared to out of school reading. Master's thesis. St. John Fisher College.

Garro, L. 2014. The importance of reading fiction. Master's thesis. University of Central Missouri.

Gilbert, G.N. Ed. 2008. Researching social life. $3^{\text {rd }}$ edition. London: Sage.

Guthrie J.T., Morrison, D.A. and Klauda, S.L. 2012. Motivation, achievement and classroom contexts for information book reading. In Adolescents' engagement in academic literacy. J.T. Guthrie, A. Wigfield and S.L. Klauda, Eds. College Park, MD: University of Maryland.

Holden, J. 2004. Creative reading: young people, reading and public libraries. London: Demos.

Howard, V. 2011. The importance of pleasure reading in the lives of young teens: self-identification, self-construction and self-awareness. Journal of Librarianship and Information Science, 43(1): 46-55.

Howie, S., Venter, E. and Van Staden, S. 2008. The effect of multilingual policies on performance and progress in reading literacy in South African primary schools. Educational Research and Evaluation, 14(6): 551-560.

Hughes-Hassell, S. and Lutz, C. 2006. What do you want to tell us? A survey of the habits and attitudes of urban middle school students toward leisure reading. Young Adult Library Services, 39: 1-8.

Hughes-Hassell, S. and Rodge, P. 2007. The leisure reading habits of urban adolescents. Journal of Adolescent \& Adult Literacy, 51(1): 22-33.

Ibarra-Guyos, V.P. 2013. Antecedents of leisure reading. International Journal of Information Technology and Business Management, 13(1): 1-11.

Johnson, R.B., Onwuegbuzie, A.J. and Turner, L. 2007. Toward a definition of mixed methods research. Journal of Mixed Methods Research, 1(2): 112-133.

Krashen, S. and McQuillan, S. 2007. Early intervention at every age: the case for late intervention. There are effective late interventions - and one of them is free. Educational Leadership, 65(2): 68-73.

Krueger, R.A. and Casey, M.A. 2001. Social analysis: selected tools and techniques. Washington DC: The World Bank.

Kutay, V. 2014. A survey of the reading habits of Turkish high school students and an examination of the efforts to encourage them to read. PhD thesis. Loughborough University.

Lategan, I.A.S. 1999. Guidelines for teaching of reading in the intermediate phase within the context of inclusion. PhD thesis. University of South Africa.

Mahwasane, N.P. 2008. Provision of library services to disadvantaged children in rural areas of the Limpopo province. Master's thesis. University of South Africa.

Mathewson, G.C. 2004. Model of attitude influence upon reading and learning to read. In Theoretical models and processes of reading. R.B. Ruddell \& N.J. Unrau, Eds. Newark: International Reading Association. 1431-1461.

McClure, L.M. 2011. The interest of grade 10 learners in reading for leisure at two schools in western Johannesburg. Master's thesis. University of Johannesburg.

McDougal, P. 2011. A survey and analysis of middle school student voluntary independent reading behaviors. PhD thesis. University of Oregon. 
McKenna, M.C. 1994. Toward a model of reading attitude acquisition. In Fostering the love of reading: the affective domain in reading education. E.H. Cramer \& M. Castle, Eds. Newark: International Reading Association.

McKenna, M.C., Conradie, K., Lawrence, C., Jang, B.G. and Meyer, J.P. 2012. Reading attitudes of middle school students: results of a U.S. survey. Reading Research Quarterly, 47(3): 283-306.

McKool, S.S. 2007. Factors that influence the decision to read: an investigation of fifth grade students' out-of-school reading habits. Reading Improvement, 44(3): 111-131.

Moyer, J.E. 2011. "Teens today don't read books anymore": a study of differences in comprehension and interest across formats. PhD thesis. University of Minnesota.

Mullis, I.V.S., Martin, M.O., Kennedy, A.M. and Foy, P. 2007. PIRLS 2006 International Report. Chestnut Hill, MA: TIMSS \& PIRLS International Study Center, Lynch School of Education, Boston College. [Online]. https://timssandpirls.bc.edu/PDF/PIRLS2006_international_report.pdf (23 May 2019).

National Endowment for the Arts. 2007. To read or not to read: a question of national consequence. Washington, DC: National Endowment for the Arts. [Online]. https://www.arts.gov/sites/default/files/ToRead.pdf (11 March 2014).

North West Development Corporation. 2019. Economic Data Report. Quarter 2 of 2019/2020. Research and Innovation. Potchefstroom: North West Development Corporation. [Online]. https://nwdc.co.za/wpcontent/uploads/2019/10/NWDC_Economic_Data_Report_Qtr_2_2019-2020.pdf (24 May 2019).

Onwuegbuzie, A.J. and Leech, N.L. 2006. Linking research questions to mixed methods data analysis procedures. The Qualitative Report, 11(3): 474-498.

Paratore, J.R. and Dougherty, S. 2011. Home differences and reading difficulty: handbook of reading disability research. New York: Routledge.

Phasha, N., McClure, L. and Magano, D. 2012. The book and the banknote: reading for leisure amongst $10^{\text {th }}$ grade learners in South Africa. Anthropologist,14(4): 319-326.

Pilgreen, J.L. 2000. The SSR handbook: how to organize and manage a sustained silent reading program. Portsmouth, $\mathrm{NH}:$ Heinemann Boynton/Cook.

Pretorius, E. and Ribbens, R. 2005. Reading in a disadvantaged high school: issues of accomplishment, assessment and accountability. South African Journal of Education, 25(3): 139-147.

Rabiee, F. 2004. Focus-group interview and data analysis. Proceedings of the Nutrition Society, 63(4): 655-660.

Ross, C.S. 2009. Reader on top: public libraries, pleasure reading, and models of reading. Library Trends, 57(4): 632656.

Smith, N.L. 2009. A study of middle grade students' reading interests, habits and achievement. PhD thesis. University of North Carolina.

Snyman, M. 2006. Die leesvoorkeure enleesgedrag van Afrikaanse kinders. Mousaion, 24(1): 145-79.

South African Book Development Council. 2007. Snapshots of the national survey into the reading and book reading behaviour of adult South Africans. Pretoria: Department of Arts and Culture.

Statistics South Africa. 2011. Provincial profile: North-West census 2011. [Online]. http://www.statssa.gov.za (23 November 2019).

Strommen, L.T. and Mates, B.F. 2004. Learning to love reading: interviews with older children and teens. Journal of Adolescent and Adult Literacy, 48(3): 188-200.

Tella, A. and Akande, S. 2007. Children's reading habits and availability of books in Botswana primary schools: implications for achieving quality education. The Reading Matrix, 7(2): 117-142.

Tiemensma, L. 2009. The literacy environment in support of voluntary reading: a case study in Gauteng east and the Highveld ridge. Master's thesis. University of South Africa.

Torgesen, J.K. 2002. The prevention of reading difficulties. Journal of School Psychology, 40(1): 7-26.

Wasik, B.A., Bond, M.A. and Hindman, A. 2006. The effects of a language and literacy intervention on Head Start children and teachers. Journal of Educational Psychology, 98(1): 63-74. 